\title{
THĂM DÒ KHẢ NĂNG SẢN SINH KHÁNG THỂ KHÁNG ĐỘC TỐ VI TẢO DOMOIC ACID CỦA THỎ TRẮNG NEW ZEALAND
}

\author{
Đào Việt Hà \\ Viện Hải duơng họ-Viện Hàn lâm Khoa học và Công nghệ Việt Nam \\ E-mail: daovietha69@gmail.com \\ Ngày nhận bài: 6-1-2016
}

\begin{abstract}
TÓM TĂT: Nhằm phuc vu phát triển bộ KIT ELISA phát hiện nhanh độc tố vi tảo domoic acid trong sản phẩm hải sản tại Việt Nam, kháng thể kháng độc tố này đã được thủ nghiệm thu nhận bằng liệu pháp miê̂n dịch đối với thỏ trắng New Zealand, thông qua sủ dụng $250 \mu \mathrm{g}$ và $500 \mu \mathrm{g}$ phức hơp kháng nguyên domoic acid - dissuccinyl substrate - bovine serum albumin. Thỏ đáp ứng miễn dịch sau 5 tháng thí nghiệm ở liều kháng nguyên $500 \mu \mathrm{g}$ và chỉ một trong số 4 cá thể thỏ có hiệu úng miễn dịch cao $(O D>3,0)$. Hiệu ứng miến dịch này có xu huớng tăng nhanh và đạt giá trị cực đại sau tháng thú 6, sau đó giảm nhanh ở các tháng tiếp theo. Dãy phát hiện domoic acid của kháng thể này khá rộng với sư biến thiên khá tuyến tính ở khoảng nồng độ pha loãng tù 1/800 đến 1/51.200. Với tín hiệu nền thấp, phân biệt phản ưng duơng và âm rõ ràng, độ pha loãng $1 / 12.800$ được chọn là đơn vị hiệu giá kháng thể. Tuy hiệu giá kháng thể trong nghiên cúu này khá thấp so với trong một số nghiên cứu khác nhung không phát hiện phản ứng ức chế nào tù kainic acid, aspartic acid, glutamic acid, gamma-aminobutyric acid, globulin, proline, hydroxyproline (có cấu trúc hóa học tương tụ domoic acid) đối với kháng thể. Kết quả này cho thấy kháng thể thu nhận bằng liệu pháp này có tính đặc hiệu với domoic acid, có thể sử dụng làm vật liệu cho bộ kít domoic acid-ELISA tai Việt Nam.
\end{abstract}

Tù̀ khóa: Domoic acid, ELISA, hiệu giá kháng thể, kháng thể kháng domoic acid.

\section{MỞ ĐẦU}

Độc tố vi tảo gây mất trí nhớ tạm thời (Amnesic shellfish poisoning toxin - ASP toxin) có bản chất hóa học là domoic acid (DA) (khối lượng phân tử: 311 daltons, công thức phân tử: $\mathrm{C}_{15} \mathrm{H}_{21} \mathrm{NO}_{6}$ ); là một axit amin có ba nhóm cacboxyl tồn tại ở dạng tinh thể, tan trong nước, có tính axit. Theo Debonnel và nnk., [1], ở động vật có vú, DA hoạt động như chất cạnh tranh glutamate, hủy hoại tế bào thần kinh bằng cách kết hợp với điểm tiếp nhận glutamate, dẫn đến tình trạng kích hoạt quá mức của tế bào. Sau khi được hấp thụ qua thành ruột và dẫn đến hệ thần kinh trung tâm, DA tác động trực tiếp đến hệ thần kinh trung tâm ở động vật bậc cao và người. Vì DA có khả năng ức chế quá trình giải phóng hoạt chất ức chế gamma-aminobutyric acid (GABA) tại vùng yên ngựa của thần kinh não bộ thông qua hoạt động kích hoạt enzyme protein kinase (PK) dạng C. Tiếp theo đó, nồng độ cao của ion Ca sẽ làm cho tế bào thần kinh trở nên sưng phồng và chết ở những vùng não bộ có quá trình trao đổi chất glutamaine-rich [2]. Các điểm tiếp nhận này tập trung nhiều nhất ở khu vực CA1 và $C A 3$ của vùng đồi hải mã, nơi có chức năng ghi nhớ và học - chính vì vậy, triệu chứng mât trí nhớ trong thời gian ngắn nhưng không hồi phục là biểu hiện đặc trưng của ngộ độc ASP ở người [3]. Takata và nnk., [4] đã phát hiện DA trong loài nhuyễn thể Spondylus tại vùng biển châu Á bao gồm Nhật Bản, Thái Lan, Philippines và Việt Nam. Tiếp theo, Đào 
Việt Hà và nnk., [5] đã công bố kết quả ghi nhận hàm lượng DA rất cao $(150 \mu \mathrm{g} / \mathrm{g}$ mô mềm) trong loài hai mảnh vỏ Hàu Hương Spondylus versicolor tại đầm Nha Phu, Khánh Hòa, Việt Nam. Hiện nay, giới hạn an toàn của độc tố DA trong sản phâm hải sản được các quốc gia chấp nhận là $20 \mu \mathrm{g} / \mathrm{g}$ mô mềm. Những phát hiện gần đây cho thây nguy cơ ngộ độc DA tại khu vực châu Á bao gồm Việt Nam đang ở mức độ cần cảnh báo.

Gần đây, hướng nghiên cứu miễn dịch học độc tố DA được quan tâm chú trọng nhiều, nhằm phục vụ phát triển phương pháp thử nghiệm nhanh đối với độc tố này bao gồm phương pháp gắn kết enzyme (ELISA). Một khó khăn rất lớn trong phát triển phương pháp ELISA đối với độc tố $\mathrm{DA}$ là cân có nguồn kháng thể đặc hiệu kháng $\mathrm{DA}$ bằng liệu pháp gây miễn dịch ở một số đối tượng động vật (cừu, dê, thỏ, chuột ....). Tuy nhiên, cơ thể sinh vật chỉ sản sinh được kháng thể kháng lại những độc tố có bản chất protein. Trong khi đó, DA có khối lượng phân tử thấp, không thuộc nhóm protein nên cơ thể sinh vật không có phản ứng miễn dịch khi bị tiêm trực tiếp độc tố. Muốn gây được hiệu ứng miễn dịch của động vật thử nghiệm đối với $\mathrm{DA}$, cần phải tạo phức hợp kháng nguyên bằng cách thực hiện phản ứng gắn kết giữa độc tố với một loại protein thích hợp, sao cho trong phức chất tạo ra, cấu trúc và tính chất của độc tố không bị thay đổi, nhưng lại mang đặc tính của một phân tử protein. Khi phức chất độc tố-protein được đưa vào cơ thể sinh vật với liều lượng an toàn, đủ đáp ứng miễn dịch trong thời gian nhất định, sinh vật sẽ sản sinh kháng thể kháng độc tố dưới dạng cấu trúc của một phân tử protein. Do đó, các nghiên cứu miễn dịch học trong những năm gần đây chủ yếu tập trung vào cơ chế, điều kiện sản sinh kháng thể kháng độc tố DA trên đối tượng động vật thử nghiệm khác nhau [6-9].

Trên cơ sở chọn lọc các phương pháp đã công bố trên thế giới về sản xuất kháng thể đa dòng kháng độc tố $\mathrm{DA}$, bài báo này trình bày kết quả thử nghiệm gây miễn dịch ở thỏ trắng New Zealand ở điều kiện tối ưu thời gian, cách thức đưa kháng nguyên vào cơ thể sinh vật với 2 nồng độ khác nhau của cơ chất (phức hợp kháng nguyên) và theo dõi sự có mặt của kháng thể kháng độc tố DA trong huyết thanh thỏ thử nghiệm. Kết quả nghiên cứu này nhằm thu nhận kháng thể kháng DA cho mục tiêu chế tạo bộ KIT ELISA với giá thành thâp, thay thế các bộ KIT hiện đang mua từ nước ngoài, phục vụ nhu cầu thị trường Việt Nam về an toàn thực phẩm biển một cách chủ động.

\section{PHƯƠNG PHÁP NGHIÊN CỨU}

\section{Gây miễn dịch trên thỏ trắng New Zealand}

Tiếp cận và kế thừa các kết quả nghiên cứu đã có, nghiên cứu này tiến hành liệu pháp miễn dịch ở thỏ trắng New Zealand đối với kháng nguyên là phức hợp độc tố DA trong các điều kiện tối ưu về kỹ thuật tiêm, tần suất và thời gian thí nghiệm. Thí nghiệm được thực hiện trong 12 tháng $(8 / 2014-7 / 2015)$. Thỏ trắng dòng New Zealand khỏe mạnh, giới tính cái, khối lượng cơ thể $0,8 \mathrm{~kg}$ được lựa chọn, sử dụng 3 cá thể cho lô đối chứng và 5 cá thể cho mỗi lô thí nghiệm. Trong thời gian thí nghiệm, thỏ được nuôi theo quy trình nuôi động vật thí nghiệm của Viện Vắc xin và Sinh phẩm Y tế [10]. Trước khi gây đáp ứng miễn dịch, huyết thanh thỏ được kiểm tra để đảm bảo không có kháng thể kháng độc tố DA trước đó.

Liệu pháp gây miễn dịch cho mỗi thỏ gồm 24 mũi tiêm dưới da bên đùi trái, tần suất 2 tuần. Thí nghiệm bao gồm 3 nghiệm thức là lô đối chứng sử dụng dịch tiêm là đệm $\mathrm{PBS}$ và tá chất, 2 lô thí nghiệm sử dụng phức hợp kháng nguyên domoic acid - dissuccinyl substrate bovine serum albumin (DA-DSS-BSS) đã được điều chế theo Đào Việt Hà và Phạm Xuân Kỳ [11] với liều tiêm 250 (nghiệm thức 1 ) và $500 \mu \mathrm{g} / \mathrm{mL}$ (nghiệm thức 2), cụ thể như sau:

Miên dịch kích thích: Tiêm vào dưới da ở vị trí đùi trái của thỏ hỗn hợp của $1 \mathrm{~mL}$ đệm PBS $(\mathrm{pH} 7,4)$ và tá chất Fraund hoàn chỉnh FCA (Freund's complete adjuvant) (WAKO, 014-09541, Nhật Bản) (tỉ lệ 1:1 về thể tích) có chứa 250 (thí nghiệm 1) và $500 \mu \mathrm{g}$ phức hợp kháng nguyên BSA-DSS-DA (thí nghiệm 2). Thực hiện liệu pháp tiêm này 2 tuần/mũi trong tháng đầu tiên.

Miên dịch nhắc lại: Từ tháng thứ 2 trở đi, tiêm dưới da ở vị trí đùi trái của thỏ hỗn hợp của $1 \mathrm{~mL}$ đệm $\mathrm{PBS}(\mathrm{pH} 7,4)$ và tá chất Fraund không hoàn chỉnh FIA (Freund's incomplete adjuvant) (WAKO, 011-09551, Nhật Bản) (tỉ lệ 
1:1 về thể tích) có chứa 250 (thí nghiệm 1) và $500 \mu \mathrm{g}$ phức hợp kháng nguyên 500 g (thí nghiệm 2) với tuần suất 2 tuẩ/lần.

Đối với 3 thỏ của lô đối chứng, tất cả các lần tiêm sử dụng $1 \mathrm{~mL}$ dung dịch hỗn hợp đệm PBS và tá chất hoàn chỉnh (FIC) (tỉ lệ $1: 1$ về thể tích).

\section{Thu nhận huyết thanh thỏ thử nghiệm}

Từ tháng thứ 5 của thí nghiệm gây miễn dịch (1/2015), tiến hành trích ly $1 \mathrm{~mL}$ máu từ động mạch vành tai (artery vent) của mỗi thỏ với tần suất hàng tháng. Ly tâm máu ở 3.000 vòng/phút trong 5 phút bằng máy ly tâm Universal 320 (Hettich, Đức) để thu nhận huyết thanh (dịch trong) và bảo quản ở điều kiện nhiệt độ $-20^{\circ} \mathrm{C}$ cho đến khi sử dụng.

\section{Kiểm tra đáp ứng miễn dịch}

Đáp ứng miễn dịch được xác định bằng hoạt tính kháng thể trong huyết thanh thỏ thử nghiệm, sử dụng phương pháp ELISA gián tiếp gồm các bước cô định kháng nguyên DA đã biết trước nồng độ, phản ứng với kháng thể kháng DA trong huyết thanh thỏ (pha loãng 1.000 lần) và phát hiện bằng phản ứng màu với cơ chất TMB (tetramethylbenzidine) thông qua kháng thể thứ cấp Polyclonal Swine anti-rabbit IgG horseradish peroxidase (DAKO, P0399, Đan Mạch), đo mật độ quang (Optical density OD) trên máy quang phố kế (Microplate Reader, MTP-810Lab, Japan) ở bước sóng $490 \mathrm{~nm}$ theo Takata [12].

\section{Xác định hiệu giá kháng thể}

Huyết thanh thỏ ở sau tháng thứ 6 có hoạt tính kháng thể cao nhất được sử dụng cho xác định hiệu giá kháng thể với dung dịch DA chuẩn (TOCRIS, UK) $1 \mu \mathrm{g} / \mathrm{mL}$ (trong đệm $\mathrm{PBS}, \mathrm{pH} 7,4)$ ở nồng độ huyêt thanh pha loãng lần lượt là $50,100,200,400,800,1.600,3.200$, $6.400,12.800,25.600,51.200$ và 102.400 lần trong dung dịch đệm PBS pH 7,4.

\section{Kiểm tra tính đặc hiệu của kháng thể trong huyết thanh}

Phản ứng ELISA được thực hiện với DA, kainic acid, aspartic acid, glutamic acid, gamma-aminobutyric acid, globulin, proline, hydroxy proline (các hóa chất này có xuất xứ từ hãng WAKO, Nhật Bản) với nồng độ của từng chất là 0,$5 ; 1 ; 2 ; 5 ; 10 ; 20 ; 100 ; 200$ và $500 \mathrm{nM}$ theo cơ chế phản ứng ELISA [12].

\section{KẾT QUẢ VÀ THẢO LUẬN}

Tất cả mẫu huyết thanh của thỏ lô đối chứng và 2 lô thí nghiệm vào thời điểm trước khi tiêm kháng nguyên đều cho kết quả âm tính trong phép thử ELISA. Như vậy, có thể khẳng định ở điều kiện không gây miễn dịch với phức hợp kháng nguyên DA-DSS-BSA, sinh vật không sản sinh kháng thể tương ứng. Sau 4 tháng thí nghiệm, 1 trong số 5 thỏ của nghiệm thức 2 bị chết chưa rõ nguyên nhân. Ở nghiệm thức 1 , các mẫu huyết thanh của cả 5 thỏ từ tháng thứ 5 cho đến tháng thứ 12 đều cho kết quả âm tính với kháng nguyên DA trong phép thử ELISA (số liệu không chỉ ra trong bài này). Như vậy, ở liều phức hợp kháng nguyên $250 \mu \mathrm{g}$, thỏ hoàn toàn không có biểu hiện đáp ứng miễn dịch.

Ở nghiệm thức 2, sau 4 tháng vẫn chưa phát hiện được hiệu giá kháng thể trong huyết thanh của thỏ thí nghiệm. Tuy nhiên, sau 5 tháng thí nghiệm, huyêt thanh cả 4 thỏ đều cho kết quả dương tính trong phép thử ELISA $\left(\mathrm{OD}_{490}>1,0\right)$, chứng tỏ đã xuât hiện đáp ứng miễn dịch ở thỏ thí nghiệm đối với liều phức hợp kháng nguyên $500 \mu \mathrm{g}$ (hình 1). Tuy nhiên, có sự khác biệt thống kê $(\mathrm{P}<0,05)$ về đáp ứng miễn dịch giữa các thỏ trong nghiệm thức này trong đó, cá thể thỏ số 1 có biểu hiện đáp ứng miển dịch cao hơn rõ rệt. Hiệu ứng miễn dịch có xu hướng tăng nhanh và đạt giá trị cực đại ở sau tháng thứ 6 , sau đó có chiều hướng giảm từ sau tháng thứ 7. Ở những tháng cuối của thí nghiệm (912), các thỏ hầu như không biểu hiện đáp ứng miễn dịch. Thời gian xuất hiện hiệu giá kháng thể ở thỏ ở nghiên cứu này có phần chậm hơn so với một số nghiên cứu khác. Newsome và nnk., [6] ghi nhận hiệu giá kháng thể đạt giá trị cao nhất vào sau tháng thứ 4 của liệu pháp miễn dịch đối với thỏ trắng New Zealand. Khả năng đáp ứng miễn dịch của động vật thử nghiệm được ghi nhận phụ thuộc vào nhiểu yếu tô như sức đề kháng của mỗi cá thể riêng biệt, protein tải sử dụng trong phức hợp kháng nguyên, phương pháp cộng hợp và đặc biệt là hệ số cộng hợp của phân tử DA với protein tải. Newsome và nnk., [6] sử dụng phương pháp 
cộng hợp nhóm carboxyl của phân tử DA với nhóm amin sơ cấp của protein tải KLH. Phân tử DA có 3 nhóm carboxyl nên tần suất bắt cặp của phân tử DA với protein tải là cao hơn. Trong khi đó, nghiên cứu này lại sử dụng phương pháp cộng hợp nhóm amin thứ cấp duy nhất của phân tử $\mathrm{DA}$ với nhóm amin sơ cấp của protein tải BSA, thông qua cầu nối hóa học DSS. Tuy nhiên, kết quả thực nghiệm của chúng tôi cho thấy, sản phẩm phức hợp kháng nguyên điều chế bằng phương pháp này có hệ số cộng hợp DA/BSA khá khiêm tốn do phụ thuộc vào hiệu suất riêng của 2 phản ứng riêng biệt là kết hợp $\mathrm{DA}$ với $\mathrm{DSS}$, và sau đó là $\mathrm{DA}$ $\mathrm{DSS}$ với $\mathrm{BSA}$ trong quy trình điều chế phức hợp kháng nguyên [11]. Mặt khác, nhiều nghiên cứu đã chứng tỏ, tùy thuộc vào số lượng nhóm amin sơ cấp hoạt tính của phân tử, các protein tải khác nhau cũng ảnh hưởng đến sản lượng kháng thể [13-16]. So với KLH, BSA có khối lượng phân tữ nhỏ hơn, và số nhóm amin sơ cấp hoạt tính cũng nhỏ hơn, do đó khả năng bắt cặp với $\mathrm{DA}$ sẽ thấp hơn trong phản ứng cộng hợp tạo phức hợp kháng nguyên.

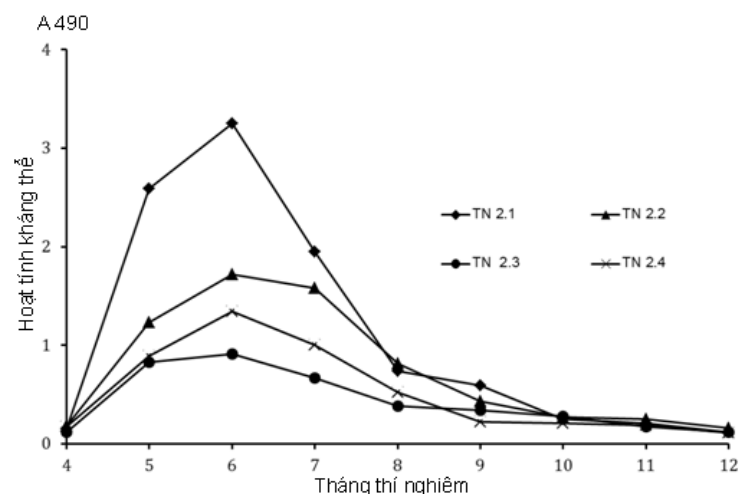

Hình 1. Hoạt tính kháng thể kháng độc tố domoic acid trong huyết thanh thỏ trắng New Zealand từ sau tháng thứ 4 đến sau tháng thứ

12 của liệu pháp miê̂n dịch với liều kháng nguyên $500 \mu \mathrm{g}$ (TN 1: thỏ thí nghiệm số 1, TN 2: thỏ thí nghiệm số 2, TN 3: thỏ thí nghiệm số 3, TN 4: thỏ thí nghiệm số 4)

Hình 2 biểu diễn hiệu giá miễn dịch của mẫu huyết thanh từ 4 cá thể thỏ trong nghiệm thức 2 sau 6 tháng trong thí nghiệm gây miễn dịch, với các nồng độ pha loãng khác nhau. Như vậy, dãy phát hiện DA đối với kháng thể được tạo ra khá rộng (trong khoảng nồng độ pha loãng từ $1 / 50$ đến $1 / 102.400)$. Ở khoảng nồng độ pha loãng $1 / 800$ đến $1 / 51.200$, sự biến thiên của kháng thể khá tuyến tính. Ở độ pha loãng $1 / 12.800$, tín hiệu nền rất thấp, không ảnh hưởng đến kết quả của xét nghiệm, mặt khác, sự khác biệt giữa phản ứng dương và âm rõ ràng, do đó, chúng tôi chọn hiệu giá kháng thể là 12.800. Tuy nhiên, nồng độ pha loãng lớn nhất vẫn có sự tạo thành phức hợp kháng nguyên-kháng thể trong thí nghiệm này là $1 / 102.400$, vẫn còn khá thấp so với một số nghiên cứu khác [13-16]. Theo nhiều tác giả, việc tạo ra đáp ứng miễn dịch ở sinh vật thử nghiệm sử dụng phức hợp kháng nguyên điều chế từ bán kháng nguyên sẽ khó khăn hơn quy trình thông thường với kháng nguyên có bản chất protein.

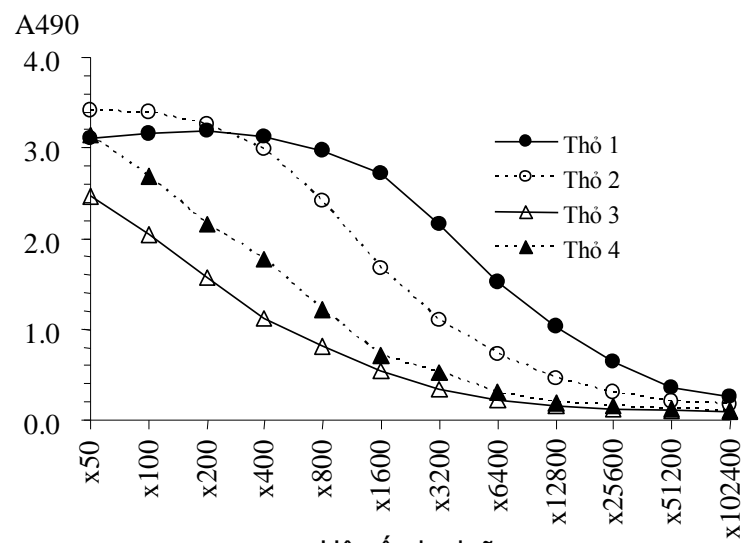

Hệ số pha loãng

Hình 2. Hiệu giá kháng thể của huyết thanh thỏ trắng New Zealand thu nhận bằng liệu pháp miễn dịch

Kết quả thử nghiệm phản ứng chéo giữa huyết thanh thỏ trắng New Zealand chứa hoạt tính kháng thể với DA và một số chất có cấu trúc tương tự được biểu diễn ở hình 3 . Như vậy, không phát hiện thấy hiệu ứng ức chế của kháng thể thu nhận được trong huyết thanh thỏ đối với bất kỳ hợp chất thử nghiệm nào ngoài phân tử $\mathrm{DA}$, chứng tỏ kháng thể này đặc hiệu chỉ với phân tử độc tố này. Kết quả này hoàn toàn tương đồng với kết quả nghiên cứu ở phương pháp tạo kháng thể đơn dòng trong một số nghiên cứu khác [13-16]. Mặc dù đây là kháng thể đa dòng được thu nhận từ liệu pháp gây miê̂n dịch trên thỏ, nhưng sản phẩm này có độ đặc hiệu tương đương với kháng thể đơn 
dòng ở một số nghiên cứu trước đây. Kết quả này là do lựa chọn phương pháp điều chế phức hợp kháng nguyên tối ưu cho mục đích nâng cao độ đặc hiệu của nghiên cứu này. Smith và Kitts [17], Osada và nnk., [8] đã gắn kết $\mathrm{DA}$ và BSA với sự có mặt của Ethyl dimethylaminopropyl carbondiimide (EDC) và $\mathrm{N}$-hydroxysuccinimide (NHS) đóng vai trò hoạt hóa nhóm amin thứ cấp của phân tử protein $\mathrm{BSA}$, sau đó gắn với 3 nhóm cacboxyl của phân tử DA thông qua liên kết kiểu peptide nên kháng thể sản sinh sẽ ở dạng hỗn hợp 3 kháng thể tương ứng với 3 điểm tiểp nhận khác nhau của phân tử DA. Nhằm cải thiện chất lượng kháng thể (có tính đặc hiệu hơn), Garthwaite và nnk., [9] đã gắn nhóm amin của DA với nhóm carboxyl của protein tải với hy vọng tận dụng với 1 nhóm amin tự do duy nhất của $\mathrm{DA}$ để giảm thiểu được tạp chất không mong muốn trong sản phẩm miễn dịch. Bằng phương pháp này, kháng thể sản sinh ra có sản lượng và tính đặc hiệu cao hơn hẳn so với Smith and Kitts [17]. Tuy nhiên, do DA chỉ có nhóm amin thứ cấp $(-\mathrm{NH})$ nên cần phải chuyển đổi sang dạng amin sơ cấp $\left(-\mathrm{NH}_{2}\right)$ trước khi tạo phức kháng nguyên, có thể làm hao hụt đi phần nào kháng nguyên sau điều chế nên quy trình thực hiện này lại quá phức tạp và tốn kém. Khác với các nghiên cứu trước đây, nghiên cứu này cộng hợp nhóm amin thứ cấp duy nhất của phân tử DA với nhóm amine sơ cấp của protein tải BSA với sự tham gia của DSS mang tính cầu nối giữa 2 gốc amin. Phương pháp này đơn giản và ít tốn kém hơn so với Garthwaite và nnk., [9, 12]. Mặt khác, do tính duy nhất của nhóm amin sơ cấp trong phân tử DA, kháng nguyên sẽ chỉ có đồng nhât 1 dạng epitopi (điểm tiếp nhận), do đó sẽ cho sản phâm kháng thể tương ứng với độ đặc hiệu cao hơn.

Kết quả thí nghiệm này rất quan trọng để xác định khả năng ứng dụng của kháng thể kháng DA sản xuất từ quy trình gây miễn dịch này nhằm phát hiện, điều tra sự có mặt của DA trong sản phẩm hải sản bằng phương pháp ELISA. Sato và nnk., [18] xác định rằng một số hợp chất đồng phân của DA như kainic acid đôi khi được tìm thấy đồng thời trong 1 số loài vi tảo sản sinh $\mathrm{DA}$, nhưng chưa có ghi nhận về hiệu ứng độc đối với người và động vật bậc cao của hợp chất này. Do đó, giám sát an toàn thực phẩm đối với độc tố DA cần loại trừ sự có mặt của kainic acid nhằm tránh sai số dương trong phép thử ELISA. Với độ đặc hiệu của kháng thể thu nhận được từ quy trình thực nghiệm này, hoàn toàn có thể đáp ứng yêu cầu này.

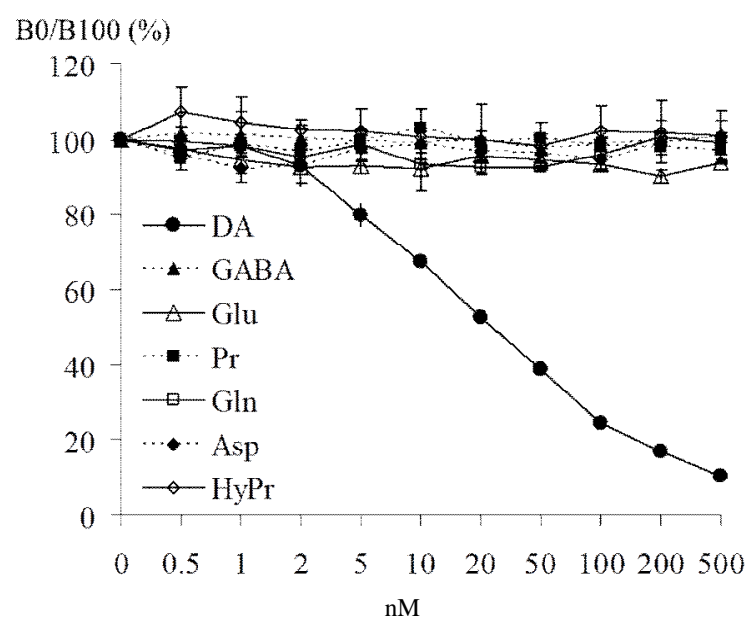

Hình 3. Kết quả phép thử ELISA giữa kháng thể trong huyết thanh thỏ thử nghiệm với domoic acid (DA) và một số chất cấu trúc tương tự - KA: kainic acid, Asp: aspartic acid,

GABA: gamma-amino butyric acid; Glu: globulin; Pro: proline, Hypro: hydroxy proline

\section{KẾT LUẬN}

Ở liều $500 \mu \mathrm{g}$ phức hợp kháng nguyên DADSS-BSA, thỏ trắng New Zealand biểu hiện đáp ứng miễn dịch sau 5 tháng thí nghiệm. Hoạt tính kháng thể kháng domoic acid trong huyết thanh thỏ đạt giá trị cực đại sau 6 tháng thí nghiệm và giảm nhanh ở các tháng sau đó. Có sự khác biệt về hoạt tính kháng thể kháng domoic acid trong huyết thanh giữa các thỏ thí nghiệm, trong đó chỉ có một trong số 4 thỏ thử nghiệm có hoạt tính kháng thể cao, với đơn vị hiệu giá kháng thể đạt 12.800 . Tuy hiệu giá kháng thể không cao, kháng thể thu nhận từ liệu pháp này có độ đặc hiệu tương đương với kháng thể đơn dòng của một số nghiên cứu trước và đủ tiêu chuẩn chất lượng sử dụng làm vật liệu cho bộ KIT ELISA.

Lời cảm ơn: Bài báo này là kết quả nghiên cứu của đề tài khoa học cấp Viện Hàn lâm Khoa học và Công nghệ Việt Nam VAST 04.04/1415 "Nghiên cứu sự sản sinh kháng thể kháng độc tố vi tảo gây mất trí nhớ tạm thời cho 
Thăm dò khả năng sản sinh kháng thể kháng ...

người (domoic acid) trên đối tượng thỏ trắng nhằm phục vụ phát triển phương pháp chẩn đoán nhanh độc tố vi tảo trong sản phẩm hải sản”, với sự hỗ trợ của GS. TS. Massaki Kodama và TS. Yoshinobu Takata, Đại học Tokyo, Nhật Bản.

\section{TÀI LIỆU THAM KHẢO}

1. Debonnel, G., Beauchesne, L., and Montigny, C. D., 1989. "Domoic acid, the alleged" mussel toxin, "might produce its neurotoxic effect through kainate receptor activation: an electrophysiological study in the rat dorsal hippocampus". Canadian Journal of Physiology and Pharmacology, 67(1): 29-33.

2. Novelli, A., Kispert, J., Reilly, A., and Zitko, $V ., 1990$. Excitatory amino acids toxicity in cerebellar granule cells in primary culture. Canada diseases weekly report $=$ Rapport hebdomadaire des maladies au Canada, 16, 83-89.

3. Perl, T. M., Bédard, L., Kosatsky, T., Hockin, J. C., Todd, E. C., and Remis, R. S., 1990. An outbreak of toxic encephalopathy caused by eating mussels contaminated with domoic acid. New England Journal of Medicine, 322(25): 1775-1780.

4. Takata, Y., Sato, S., Ha, D. V., Montojo, U. M., $\quad$ Lirdwitayaprasit, $\quad T$., Kamolsiripichaiporn, S., Kotaki, Y., Fukuyo, $Y$., and Kodama, M., 2009. Occurrence of domoic acid in tropical bivalves. Fisheries Science, 75(2): 473-480.

5. Dao, H. V., Takata, Y., Omura, T., Sato, S., Fukuyo, Y., and Kodama, M., 2009. Seasonal variation of domoic acid in a bivalve Spondylus versicolor in association with that in plankton samples in Nha Phu Bay, Khanh Hoa, Vietnam. Fisheries Science, 75(2): 507-512.

6. Newsome, H., Truelove, J., Hierlihy, L., and Collins, P., 1991. Determination of domoic acid in serum and urine by immunochemical analysis. Bulletin of environmental contamination and toxicology, 47(3): 329-334.
7. Smith, D. S., and Kitts, D. D., 1995. Enzyme immunoassay for the determination of domoic acid in mussel extracts. Journal of Agricultural and Food Chemistry, 43(2): 367-371.

8. Osada, M., Marks, L. J., and Stewart, J. E., 1995. Determination of domoic acid by two different versions of a competitive enzymelinked immunosorbent assay (ELISA). Bulletin of environmental contamination and toxicology, 54(6): 797-804.

9. Garthwaite, I., Ross, K. M., Miles, C. O., Hansen, R. P., Foster, D., Wilkins, A. L., and Towers, N. R., 1998. Polyclonal antibodies to domoic acid, and their use in immunoassays for domoic acid in sea water and shellfish. Natural Toxins, 6(3-4): 93-104.

10. Lê Văn Hiệp, Lê Văn Bé, Ngô Phú, Đặng Hồng Vân, Nguyễn Ái Thuởng, Huỳnh Xuân Thanh, Bùi Văn Sơn, Trần Văn Tưu, Lâm Thành Hung và Nguyễn Toàn, 2013. Nghiên cứu xây dựng quy trình sản xuất kháng độc tố tetrodotoxin nhằm phục vụ cho công tác điều trị ngộ độc cá nóc. Báo cáo tổng kết đề tài khoa học cấp tỉnh Khánh Hòa 2010-2012.

11. Đào Việt Hà và Phạm Xuân Kỳ, 2015. Điều chế phức hợp kháng nguyên từ bán kháng nguyên domoic acid. Tạp chí Nghề cá Sông Cửu long số 6/2015: 126-132. ISBN 18591159.

12. Takata, Y., 2006. Study on the mechanism of domoic acid accumulation in shellfish (Doctoral dissertation, $\mathrm{PhD}$ Thesis, Kitasato University, Iwate).

13. Branaa, P., Naar, J., Chinain, M., and Pauillac, S., 1999. Preparation and characterization of domoic acid-protein conjugates using small amount of toxin in a reversed micellar medium: application in a competitive enzyme-linked immunosorbent assay. Bioconjugate chemistry, 10(6): 1137-1142.

14. Kawatsu, K., Hamano, Y., and Noguchi, T. (1999). Production and characterization of 
a monoclonal antibody against domoic acid and its application to enzyme immunoassay. Toxicon, 37(11): 1579-1589.

15. Kania, M., and Hock, B., 2002. Development of monoclonal antibodies to domoic acid for the detection of domoic acid in blue mussel (mytilus edulis) tissue by ELISA. Analytical letters, 35(5): 855-868.

16. Kania, M., Kreuzer, M., Moore, E., Pravda, M., Hock, B., and Guilbault, G., 2003. Development of polyclonal antibodies against domoic acid for their use in electrochemical biosensors. Analytical letters, 36(9): 1851-1863.

17. Smith, D. S., and Kitts, D. D., 1994. A competitive enzyme-linked immunoassay for domoic acid determination in human body fluids. Food and chemical toxicology, 32(12): 1147-1154.

18. Sato, M., Nakano, T., Takeuchi, M., Kanno, N., Nagahisa, E., and Sato, Y., 1996. Distribution of neuroexcitatory amino acids in marine algae. Phytochemistry, 42(6): 1595-1597.

\title{
PRODUCTION OF ANTIBODY AGAINST DOMOIC ACID IN NEW ZEALAND WHITE RABBIT
}

\author{
Dao Viet Ha \\ Institute of Oceanography-VAST
}

\begin{abstract}
In order to develop an ELISA KIT for detection of domoic acid in seafood in Vietnam, the antibody against domoic acid was produced by immunizing in New Zealand white rabbit using 250 and $500 \mu \mathrm{g}$ domoic acid-dissuccinyl substrate-bolvine serum albumin as an antigen. Using $500 \mu \mathrm{g}$ of domoic acid-dissuccinyl substrate-bolvine serum albumin, antibody exhibited activity in the rabbit's serum after 5 months and only one out of 4 rabbits showed high activity $(O D>3.0)$. Antibody activity in the rabbit serum was increasing and reached maximum after 6 months of experiment, then decreased rapidly in the following months. Domoic acid antibody titer was wide in range with good correlation in 1/800 to 1/51,200 dilution. In 1/12,800 dilution, a background signal was very low, with clear distinction between negative and positive results, so this concentration was chosen as an antibody titer unit. This unit is rather lower than that in some other studies, however, antibody obtained in this study showed no cross action with any of kainic acid, aspartic acid, glutamic acid, gamma-aminobutyric acid, globulin, proline, hydroxyproline, which have similar chemical structure to domoic acid. The results showed that antibody obtained in the study is specific to domoic acid, and can be used as material for domoic acid-ELISA kit in Vietnam.
\end{abstract}

Keywords: Antibody against domoic acid, antibody titer, domoic acid, ELISA. 